\title{
Studies on some gastropods and echinoderms of the shallow water in the intertidal zone between Ras Mohamed and Dahab at the Red Sea, Egypt
}

\author{
Samir Beltagi \\ Department of Biological and Geological Sciences, Faculty of Education, \\ Ain Shams University- Cairo- Egypt
}

\begin{abstract}
Scientific work was done including some gastropods and echinoderms in the intertidal zone between Ras Mohamed and Dahab in the North Red Sea (Gulf of Aqaba). Investigations lead to the recognitions of the $1^{\text {st }}$ record of two echinodermis; Ophiocomina nigra and gastropod Clypeomorus bifasciata which are inhabiting the eastern shallow waters of the Mediterranean sea. Thus threw light to the lessepsian migration of the fauna via the Suez Canal.
\end{abstract}

Key words: Red Sea Ecology, Gulf of Aqaba, Red Sea, molluscus, echinodermis, Ophiocomina nigra, Clypeomorus bifasciata, Invertebrate systematic.

\section{INTRODUCTION}

In spite of the intensive scientific work which is merely based upon some molluscan and echinodermal families in the Indo-West-Pacific (Abbot, 1960; Burgess, 1967,1970; Cernohorsky, 1967; Habe, 1964; Kira, 1962; Powell, 1964; Rosewater, 1965; Kay, 1979), yet there is comparatively scarce information for the Red Sea, especially in the field of taxonomical studies of molluscs. In recent times, few studies were published on the faunal composition of molluscs in this region, namely that of Cypraeids (Foin, 1972; Mienis, 1971b; O'Malley, 1971; Schilder, 1965).

Further knowledge about the Zoogeography of littoral mollusks in the Red Sea zones was given for strombids (Mienis, 1970, 1971); Conids (Khon, 1965), Terebrids (Bratcher and Burch. 1967) and many families of pelecypods (Lamy, 1916), besides the collections and observations of the marine molluscan assemblages of port Sudan, Red Sea which were done by Mastaller (1978) and also of Saudi Arabia (Sharabati, 1981). Also, former extensive surveys and description were done in this field, especially that of Issel (1869), Hall and Standen (1907); Jickell (1874); Shopland (1902), Sturany (1901, 1903) and Beltagi et al. (1984, 2015.

In the present study, mollusks and echinoderms the intertidal area of the Egyptian shore of Aqaba Gulf from Ras Mohamed and Dahab were investigated.

\section{MATERIALS AND METHODS}

Field trips were carried out to the study area (Fig. 1), using a motor-boat, during the period from March 2017. Some Gastropods and echinoderms were collected by hand nets. Many kinds of specimens were collected from depths exceeding one metre, using a dredge of heavy steel frame with a non-flexible "bridle" of steel rods and a bag of heavy-duty nylon setting with a finer-meshed inner lining. The dredge used has an aperture about $20 \times 45 \mathrm{~cm}$. and a bag about $1 \mathrm{~m}$. deep.

Specimens were collected alive from the study area, generally contract and withdrew their tentacles and will die in this state unless, they are carefully narcotized. The specimens were narcotized by adding a saturated solution of Epsom $\left(\mathrm{MgSO}_{4}\right)$ to the sea water in which the specimen is contained and leave the preparation for 2 hours, after the time the specimens were preserved in $4 \%$ formalin. Larger specimens were left in narcotizing solution from 2 to 
Samir Beltagi

4 hours. More than 200 specimens were collected and preserved. The bottom of the study area is sandy and rocky without any overgrowth. At the reef, there is a very shallow back reef with a layer of rubble over hard coral rock, reading a moderate depth of about $20-80 \mathrm{~cm}$.

Shells of gastropods and the whole specimen of echinoderms were used for their identification.

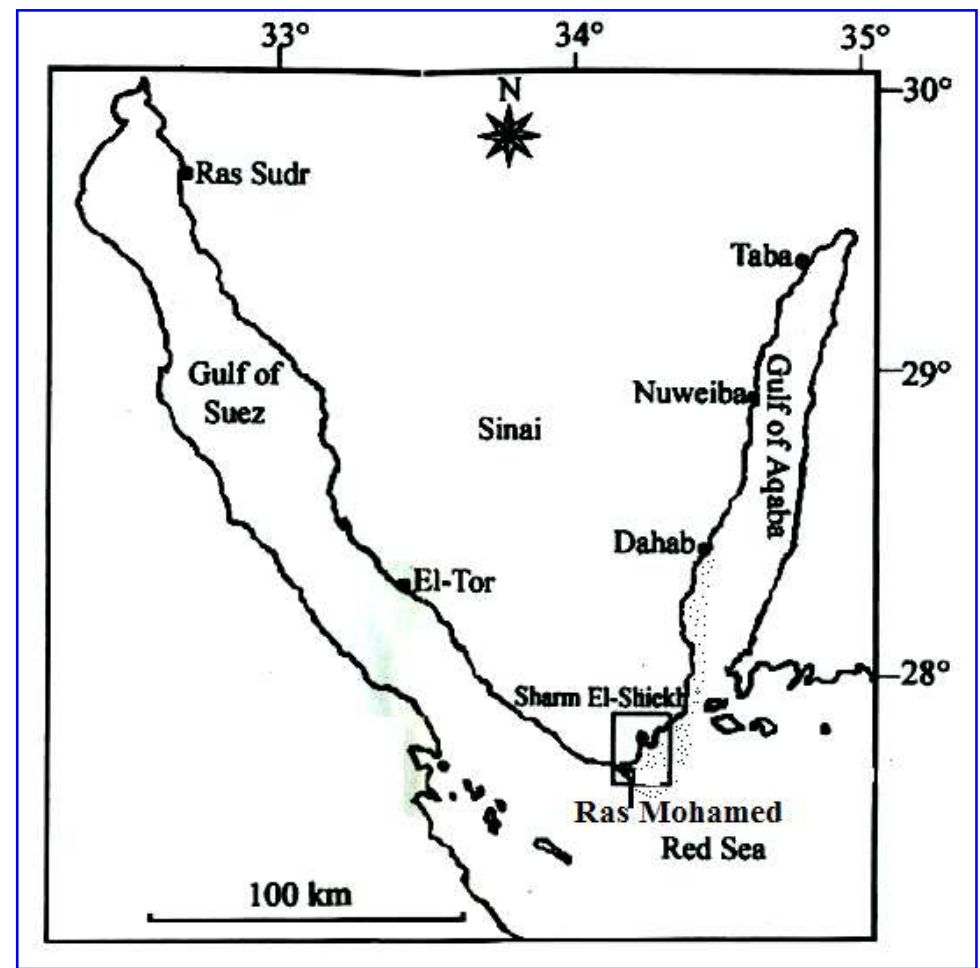

Fig. (1): Map showing sampling location between Ras Mohamed and Dahab at the Northen Red sea and Gulf of Aqaba, Egypt.

1- Strombus decorus persicus (Fig. 2)

Systematic position

Phylum: Mollusca

Class: Gastropoda

Subclass: Caenogastropoda

Order: Littorinemorpha

Family: Strombidae

Genus: Strombus (Linnaeus, 1758)

Species: decorus (Roding, 1798)

Subspecies: persicus

\section{Description:}

The shell has white to pale pink aperture which differentiated from Strombus decorus, in having an orange but rose colour. It has $2 \mathrm{~cm}$ length with depressed spire and pointed nipple like apex bumby rather knolby. Expanded lip has thin edge. Deep stromboid notch almost straight short siphonal canal, smooth columella, white broodsen axial way streaks of 
Studies on some gastropods and echinoderms of the shallow water in the intertidal zone between Ras Mohamed and Dahab at the Red Sea, Egypt

dark from forming seven spiral bands on body whorl columella heavily mottled with brown inside lip and interior pink columella and around notch with orange tinge.

Distribution: Red Sea, Suez Canal, Arabian gulf, Mediterranean Sea.

Habitat: In Rocky, Muddy and sandy intertidal zones.

1-Clanculus pharaonius (Linnaeus, 1758) (Fig. 3)

Systematic position

Phylum: Mollusca

Class: Gastropoda

Order: Vetigastropoda

Family: Trochidae

Genus: Clanculus

Species: pharaonius

\section{Description:}

Strawberry top shell, is beaded pattern usually alternates black and its length reaches about $2.5 \mathrm{~cm}$. Columella ends with a tooth and has one large and three small folds. Tooth at top of lip, projects over the umbilicus lip is finely dentate. Spiral rows of fine rounded nodules, mostly pink red but some have pearl color.

2 rows of dark purple spots on each whorl base similar but there is area, round the columella and inside lip, is white and ribbed.

Distribution: Madagascar- Indo- Pacific- Red Sea- Gulf of Oman

Habitat: Subtidal zone on Rocky substratum.

3- Conus virgo (Linnaeus, 1758) (Fig. 4)

Systematic position

Phylum: Mollusca

Class: Gastropoda

Order: Neogastropoda

Family: Conidae

Genus: Conus

Species: virgo (Linnaeus, 1758)

\section{Description:}

Shell solid to heavy. Length ranges between 50-60 mm. Periostracum brown to faint yellowish coloration. Last whorl conical, outline slightly convex, straight below. Shoulder angulated. Spire low, outline slightly concave to slightly convex. Teleoconch sutural ramps almost flat to slightly concave, late ramps with 3 increasing to 5-6 spiral grooves, either paralleled by additional striate or replaced by numerous in latest whorls. Last whorl with weak to obsolete, spiral ribs near base; widely spaced fine ribs and wrinkled threads between may extend to centre or beyond. Dorsum of foot white mottled with brown, with a crossshaped block transverse blotch on anterior part, a black blotch at opercular area. Edge of foot yellow to orange. Radula teeth long and curved, with 2 opposite adapical barbs, serration extends more than halfway down the shaft terminating in a backward pointing cusp; base with a distinct spur (Bergh, 1895; Peile, 1939; Bandel, 1984). 
Samir Beltagi

Distribution: Red Sea and in the tropical in the west pacific, India, Western Australia.

Habitat: In the intertidal rocky shores especially on dead and living corals.

4-Morula granulata (Duclos, 1832) (Fig. 5)

Systematic position

Phylum: Mollusca

Class: Gastropoda

Order: Caenogastropoda

Family: Muricidae

Genus: Morula

Species: granulata (Duclos, 1832)

\title{
Description:
}

The shell has a length of about $1.8 \mathrm{~cm}$. It is conical to oblong and compact and no varices. It is covered by black blunt knobs on a white background with spiral cords between the rows. The body whorl is covered with six rows of nodules. The narrow aperture is blackish. The outer lip is dentate with 4 to 5 teeth within. The columella and the inner lip are white. The globular shape tight shell coiling, strong sculpture.

Distribution: Indian ocean, Red sea, Indo-west pacific and Australia.

Habitat: This species lives on rocky intertidal shores and on reef flats.

\author{
5- Planaxis sulcatus (Fig. 6) \\ Systematic position \\ Phylum: Mollusca \\ Class: Gastropoda \\ Order: Caenogastropoda \\ Family: Planaxidae \\ Genus: Planaxis \\ Species: sulcatus
}

\section{Description:}

It is found in rocky intertidal environments throughout the indo-pacific region. The conical shell, speckled with patterns of white spots on a greenish-brown background. Its height ranges between 20 to $35 \mathrm{~mm}$. Planaxis sulcatus has a shell with strong squarish spiral cords; shell has a blackish to cream sometimes with white or yellowish spots. Shell opening wide, inner surface white sometimes with dark purple grooves. Operculum thin; horn-like material and dark colored; Body pale, small foot with a pale dark mottled pattern above, long tentacles with dark base. The tip of the shell is often eroded white. Inside the shell is white, with brown stripes following spirals.

The Biodiversity of the gastropod species in the research work referred to the tolerance of these fauna to the effect of the physical and chemical factors subjected to them also the type of the bottom of the upper intertidal shallow sea-water. Some gastropods is adapted to live in muddy or sandy substratum; others are living upon rocky bottom. The larval stages the collected and identified species select the suitable habitats especially where suitable salinity and temperature and the Intensity of the light and dissolved gases $\left(\mathrm{O}_{2}\right)$ exist. 
Studies on some gastropods and echinoderms of the shallow water in the intertidal zone between Ras Mohamed and Dahab at the Red Sea, Egypt

Habitat and Distribution: This species lives on rocky intertidal sea-shores, and the intertidal pools. In Red Sea. It is characteristic of the splash zone.

6- Cellana Eucosmia (Fig. 7)

Systematic position

Phylum: Mollusea

Class: Gastropoda

Order: Archaeogastropoda

Family: Patellidae

Genus: Cellana

Species: eucosmia

\section{Description:}

Shell ovate outline, very low conical with apex slightly anterior to mid-length. External sculpture of numerous, fine flat, granulose radial riblets. It has a pale brown; inside translucent with external color showing through except on the callus is variously tinged with white and brown or pale orange. The shell reaches about 2 to $2.5 \mathrm{~cm}$.

Distribution: Indo-Pacific region, Red sea, Suez canal, greater Bitter lakes Arabian gulf, Greece, Salonikos gulf.

Habitat: Collected from rocky substratum near shore level.

7- Nerita albicilla (Linnaeus, 1758) (Fig. 8)

\section{Systematic position}

Phylum: Mollusea

Class: Gastropoda

Order: Cycloneritimorpha

Family: Neritidae

Genus: Nerita

Species: albicilla (Linnaeus, 1758)

\section{Description:}

Shell with spire depressed width greater than height, sculptured with broad, low, spiral ribs. Columella deck pustulose, particularly at outer edge; columella concave centrally; smooth or with two or three weak teeth centrally. Outer lip with one or 2 strong posteriorly sometimes one anteriorly and 12-15 weak lirae. Exterior dull, black with white flecks or patches, often formed into two irregular spiral bands. Columella deck white, aperture white. Operculum calcareous, finely pustulose, grey or yellow. Shell size reaches about $16 \mathrm{~mm}$ in length.

Distribution: Indo- West pacific, Red sea, Australia.

Habitat: Shelters under rocks on open coasts between mid and low tide. It is found on rocky cliffs, on rocks in the littoral. 
Samir Beltagi

8- Engina mendicaria (Linnaeus, 1758) (Fig. 9).

Systematic position

Phylum: Mollusea

Class: Gastropoda

Order: Neogastropoda

Family: Buccinidae

Genus: Engina

Species: mendicaria (Linnaeus, 1758)

Description: The shell reaches about $1 \mathrm{~cm}$ in length. It has a white or yellowish back-ground with a few transverse black bands and resembles the yellow or black pattern of wasps and bees.

Distribution: It is found in the Red sea. Indo pacific in the tropical Australia.

Habitat: It is carnivorous, living on rocky and Sandy beds. They are nocturnal.

9- Clypeomorus bifasciata (1 ${ }^{\text {st }}$ record) (Fig. 10)

Systematic position

Phylum: Mollusea

Class: Gastropoda

Order: Caenogastrapoda

Family: Cerithiidae

Genus: Clypeomorus

Species: bifasciatus

\section{Description:}

Shell thick about twice as high as broads 7-8 rather flat whorls. Sculpture on spire whorls of 3 equally spaced beaded cords; beads prominent and aligned axially so as to form ribs. Body whorl with a blunt varix opposite the constricted siphonal canal, and opposite to it a well defined anal canal delimited by a denticle on the columella. Colour is whitish background and usually dark beads or series of dark spots on the cords; with dark spiral lines, bands or interspaces of cords the shell reaches about $15 \mathrm{~mm}$.

Distribution: Red sea, Indo-pacific - Suez Canal Medilerranean (Mienes, 1985); Port Said, Egypt (Giannuzzi-Savelli, et al 1997).

Habitat: It lives on rocky interidal zone of the Red sea.

10- Nassarius coronatus (Bruguiere, 1789) (Fig. 11).

\section{Systematic position}

Phylum: Mollusea

Class: Gastropoda

Order: Neogastropoda

Family: Nassariidae

Genus: Nassarius

Species: Coronatus (Bruguiere, 1789) 
Studies on some gastropods and echinoderms of the shallow water in the intertidal zone between Ras Mohamed and Dahab at the Red Sea, Egypt

Description: It has Moderate spire, sharply angled shoulders, with blunt heavy modules, found on body whorl, finely dentate lip ridged with columella has posterior ridge, four small teeth anteriorly callous shield. Short siphonal parietal and anal canals. White with brown band.

Habitat and Distribution: Found on sandy intertidal zone of the red sea, indo-pacific Japan - Solomon Islands and Western Australia.

11- Drupella cornus (Roding, 1798) (Fig. 12)

Systematic position

Phylum: Mollusea

Class: Gastropoda

Order: Neogatropoda

Family: Muricidae

Genus: Drupella

Species: cornus (Roding, 1798)

\section{Description:}

The shell size reaches about $2.1 \mathrm{~cm}$. It is whitish in color, showing four rows of spring pointed nodules with numerous smaller spines between. The small aperture is oval. The outer lip with 3 to 4 teeth. It has a planktonic veliger larva.

Distribution: Red sea zone and the Indian Ocean -Thailand - Japan and indo-pacific.

Habitat: Under tubular corals of the species of Acropora and Montipora living on hard rocky intertidal shores.

12- Dendropoma maximum (Fig. 13)

Systematic position

Phylum: Mollusea

Class: Gastropoda

Order: Mesogastropoda

Family: Vermetidae

Genus: Dendropoma

Species: maximum

\section{Habitat short description:}

It lives embedded in a substrate which is often a living coral. It is a dominant species of outer reef flats in the Red sea where or it may reach densities of more than $22 \mathrm{species} / \mathrm{m}^{2}$. It seems to prefer strong water movement and feeds by mucus net which is spread by wave action over the reef surface. It has tubular shell reaching about $5 \mathrm{~m}$. it is regular in shape.

Distribution: It is found in red sea attached to living corals dead shells of marine snails. 


\section{Samir Beltagi}

13- Holothuria scabra (Jaeger, 1833) (Fig. 14)

\section{Systematic position}

Phylum: Ectodermata

Class: Holothuroidea

Order: Aspidochirotida

Family: Holothuriidae

Genus: Holothuria

Species: scabra (Jaeger, 1833)

\section{Description:}

The body is soft and tapered at both ends with a short tail. Tube feet are scattered all over the body which are brown. The spicules are found all over the body and consist of four holed plates with central spires. The length of the body reaches between $10-20 \mathrm{~cm}$.

Distribution: Widespread throughout the Indo-Pacific between latitudes $30^{\circ} \mathrm{N}$ and $30^{\circ} \mathrm{S}$ (Hamel et al. 2013), from South Africa to the Red Sea, India, China and Japan to Australia, and to Micronesia in the northeast and Tonga in the southeast. In Madagascar, this species is observed in the west coast from the south of Toliara to Nosy-be (Rasolofonirina pers.Comm., 2010).

Habitat: Muddy substratum in the intertidal zone.

Remarks: Holothuria scabra and $H$. scabra var. versicolor (now H. lessoni) have recently been properly identified as distinctive species (Hamel et al., 2013).

14- Ophiocomina nigra (Abildgard, in O. F. Muller, 1789) ( $1^{\text {st }}$ record) (Figs. 15-18)

Systematic position

Phylum: Echinodermata

Class: Ophiuroidea

Order: Ophiurida

Family: Ophiocomidae

Genus: Ophiocomina

Species: nigra (Abildgard, in O. F. Muller, 1789).

\section{Description:}

It is black in color length reaches about $2 \mathrm{~cm}$ across. The upper surface of the disc is covered with fine granules. On the underside, the granules are limited to the outer portion and the plates are visible towards the central mouth. The Aristotles lantern with 5 toothed jaws. There is a comb like arrangement of spines down either side of the arms giving them a bristly appearance. On the upper side each arm segment is covered by a broad plate with 5 to 7 spines. On the underside there are tube feet without suckers.

Habitat and Distribution: It is found on rocks and gravel in the Neritic zone. It occurs in Eastern Atlantic Ocean. Mediterranean Sea. North Sea-Red Sea.

\section{DISCUSSION}

The movement of the surface water current in the Red Sea has an effect on the distribution of zooplanktonic elements along the whole length of the Red Sea. This fact appear in the presence of some species of gastropods on the western side as well as the eastern one. Also, lessepsian migration plays an important role in the presence of some 

between Ras Mohamed and Dahab at the Red Sea, Egypt

species of gastropods and Echinoderms in both inhabitable locations Eastern intertidal zones of the Mediterranean Sea and the Northern part of the Red Sea.

\section{Acknowledgments}

I would like to thank Prof. Dr.Mohamed Hamed the head of the Biological and Geological Department for his sincere assistance to this research work, and the Assistant lecturer Taha Abd El Shafey and Mr. Magdy Maduen Laboratory specialist.

\section{REFERENCES}

Abbot, R.T. (1960). The Genus Strombus in the Indo-Pacific, Indo-Pacific Mollusca, 1(2): 33-146.

Beltagi, S. and Gamrawy M.S. (1984). Studies on some pelecypods and Gastropods of shallow water in the region of North, Jeddah (Red sea) Prof. Symp. Coral reef environment Red sea, Jeddah 1984; 417-470.

Beltagi, S. (2015). Further studies on Bivalves inhabiting the inter tidal zones of Port saied, Fayed and Hurghada, Egypt. Inter. J. Develop., 4(1): 115-123.

Bratcher, T. and Burch D. (1967). A new Terebrid species with checklist of Terebridae from the Red Sea (Mollusca, Gastropods). The Veliger, 10(1): 7-9.

Bruguiere, J.G. (1789). Encyclopedia Methodique. Histoire Naturelle des Vers et Mollusques 1: 236-285.

Burgess C. M., 1967). Marine Shells of the Pacific. Sydney: Pacific Publications, 248pp.

Burgess, C.M. (1970). The living cowries A. S. Barnes and Co. New York, 1-380.

Duclos, R. (1832). Retrieved World Register of Marine Species on 19 November 2010. Retrieved through Cernohorsky O.W. (1967). The Bursidae, Cymatiidae and Colubrariida of Fuji Veliger, 9(3): 310-329. At: : (Http://ww.marinespectespecies. org/aphia.php? $\mathrm{p}=$ taxdetails\&id=208557)

Foin, T.C. (1972). The zoogeography of the Cypraeidae in the Red Sea basin-Argamon, Israel J. Malacol., 3(1-4): 5-16.

Giannuzzi-Saelli, R.; Pusateri, F.; Palmeri, A. and Ebreo, C. (1997). Atlante delle conchiglie marine del mediterraneo. Vol. 2: Caenogastropoda. La Conchiglia, Roma, 258p.

Habe, T. (1964). Shells of the Western Pacific in color, II Hoikusha Publ. Co. Osaka: 1-233.

Hall, W.J. and Standen, R. (1907). On the Mollusca of a raised coral feer on the Red Sea coast, J. Conch., 12(3): 65-68.

Hamel, J.-F.; Mercier, A.; Conand, C.; Purcell, S.; Toral-Granda, T.-G. and Gamboa, R. (2013).Holothuria scabra. The IUCN Red List of Threatened Species 2013. At http://dx.doi.org/10.2305/IUCN.UK.2013-1.RLTS.T180257A1606648.en.

Issel A. (1869). Malacologia del Mer Rosso. Pisa: 1-387.

Jickeli, C.F. (1874). Studien uber die Conchylien des Rothen Meeres I. Die Gattung Mitra.Jahrb. Deutsch. Malakizool. Ges, I: 17-54.

Kay, E.A. (1979). Hawaiian Marine Shells. Reef and shore Fauna of Hawaii. Section 4: Mollusca. Bernice P. Bishop Museum Special Publication 64(4). Bishop Museum Press Honolulu, Hawaii.

Khon, A.J. (1965). Conus (Mollusca, Gastropoda) collected by the Israel South Red Sea Expedition 1962, with notes from the Gulf of Aqaba Sinai Peninsula-Sea Fish. Res. Sta. Haifa Bull., 38: 54-59.

Kira, T. (1962). Shells of the Western Pacific in color. Osaka Hoikusha.

Lamy, E. (1916). Les Mactres et les lutraires de la Mer Rouge. Bul. Mus. Nat. Hist. Nat. Paris, 22: 237-309.

Lamy, E. (1917). Les Arches de la Mer Rouge. Bull. Mus. Nat. Paris, 23: 1-6. 


\section{Samir Beltagi}

Linnaeus, C. (1758). Systema naturae per regna naturae, (Editio decimal, reformata) Stockholm.

Mastaller, M. (1978). The Marine Molluscan assemblages of port Sudan, Red Sea. Zoologische Mededelingen Uitgegevan Door Het. Ijksmuseum van natuurlijke Historie te Leiden (Ministerie van Cultuur, Recreatie en Maatschappelijk Werk) Deel 53 no. 13. Ruhr-Universitat Bochum, Lehrstuhl fur Spez. Zoologie Bochum, West Germany with one text-figure and one table.

Mienis H. K. (1970). A checklist of Terebridae from the northern part of the Red Sea, with notes on Terebra arcolata. T. consobrina and T. subulata. Jour. Isr. Malacol. Soc., $1(2)$.

Mienis H. K (1971a). Strombidae (Mollusca, Gastropoda) collected by the Israel South Red Sea Expedition 1962. Argamon, 2.

Mienis H. K. (1971b). Capracidae from the Sinai area of the Red Sea. Argamon, 2(1-2): 1344.

O'Malley, J. (1971). Identification Guide: Cowries of the Jeddah Red Sea Area of sea and shore publ., 1-16.

Powell, A.W.B. (1964). The family Turridae in the Indo-Pacific. Part I. The subfamily Turrinae. Indo-Pacific Mollusca, 1(5): 227-345.

Roding, K. (1798). Retrieved World Register of Marine Species on 24 April 2010. (Http://ww.marinespectespecies.org/aphia. $\mathrm{php}$ ? $\mathrm{p}=$ taxdetails\&id=212155).

Rosewater, I. (1965). The family Tridacindae in the Indo-Pacific. Indo-Pacific Molluscs, 1(6): 347-306

Schilder, F.A. (1965). The Cypraeidae of the Israel South Red Sea expedition 1962. Sea Fish. Res. Sta. Haifa Bull., 40: 75-78.

Sharabati, D. (1981). Saudi Arabian sea-shells selected Red Sea and Arabian Gulf Molluscs. Library of Congress Catalog Card Number 81-52534. Printed in the Netherlands by Royal Smeets offset B. V. Weest.

Shopland, F.R. (1902). List of marine shells collected in the neighbourhood of Aden between 1802 and 1901. Proc. Ma1. Soc. London, 5(2): 171-179.

Sturany, R. (1901). Lamellibranchiaten des Roten Meeres. Ber. Comm. Ocean. Forschungen., 7: 225-205.

Sturany, R. (1903). Gastropoden des Roten Meeres. Denkschr. Math-naturwiss. Cl. K. Akad. Wiss. Wien., 74: 210-283. 
Studies on some gastropods and echinoderms of the shallow water in the intertidal zone between Ras Mohamed and Dahab at the Red Sea, Egypt

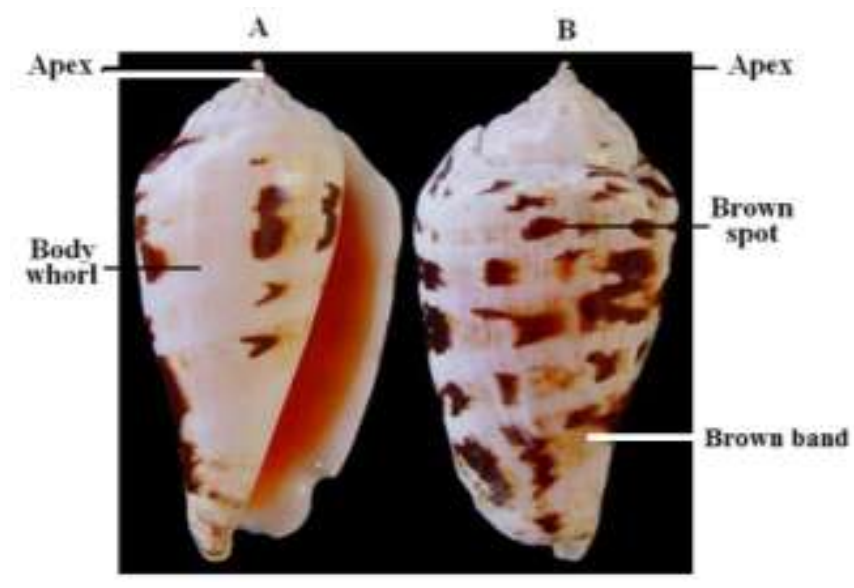

Fig. (2):Photomicrograph of shell of Strombus decorus persicus.
(A) Ventral view
(B) Dorsal view

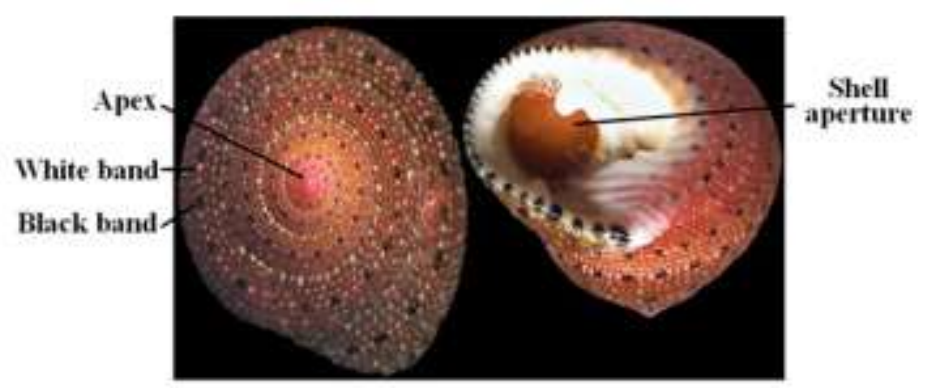

Fig. (3):Photomicrograph of shell of Clanculus pharaonius.

(A) Dorsal view (B) Ventral view
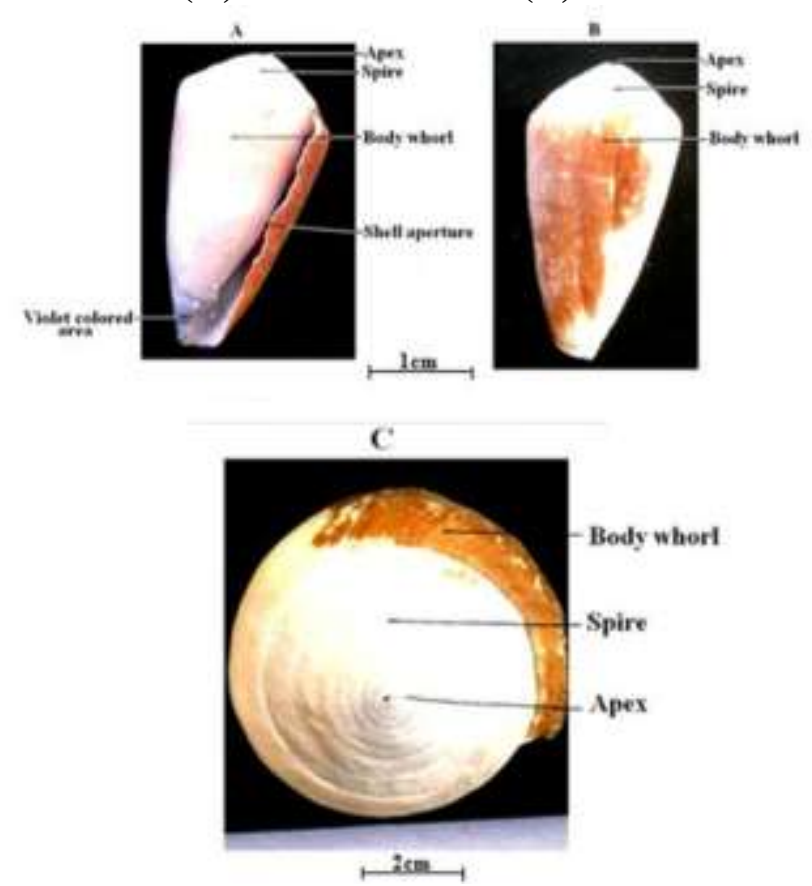

Fig. (4): Photomicrograph of shell of Conus virgo

Ventral view (B) Dorsal view (C) Top view of spiral 
Samir Beltagi

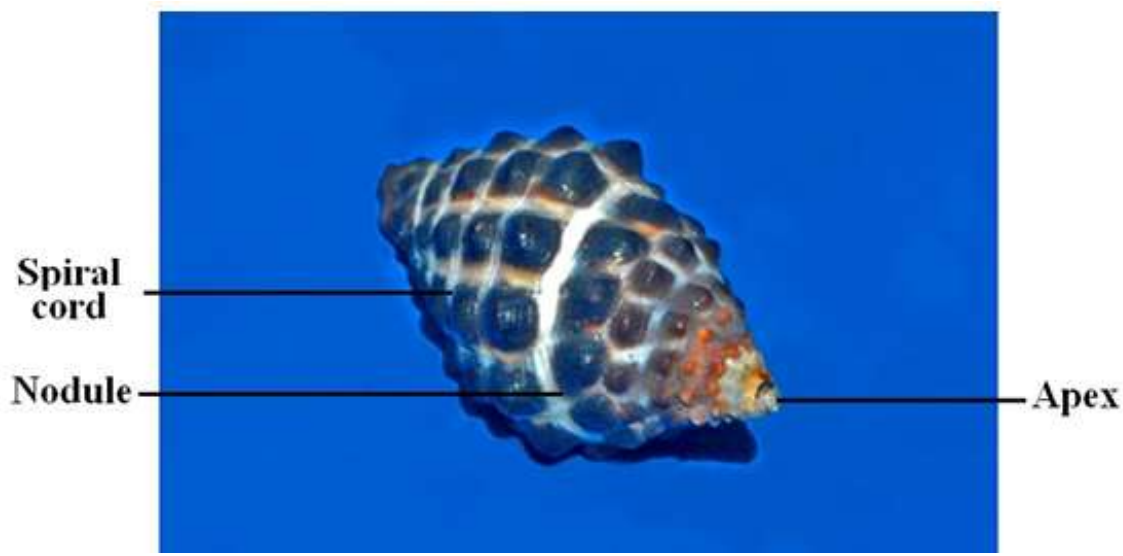

Fig. (5): Photomicrograph of shell of Morula granulate (Dorsal view)

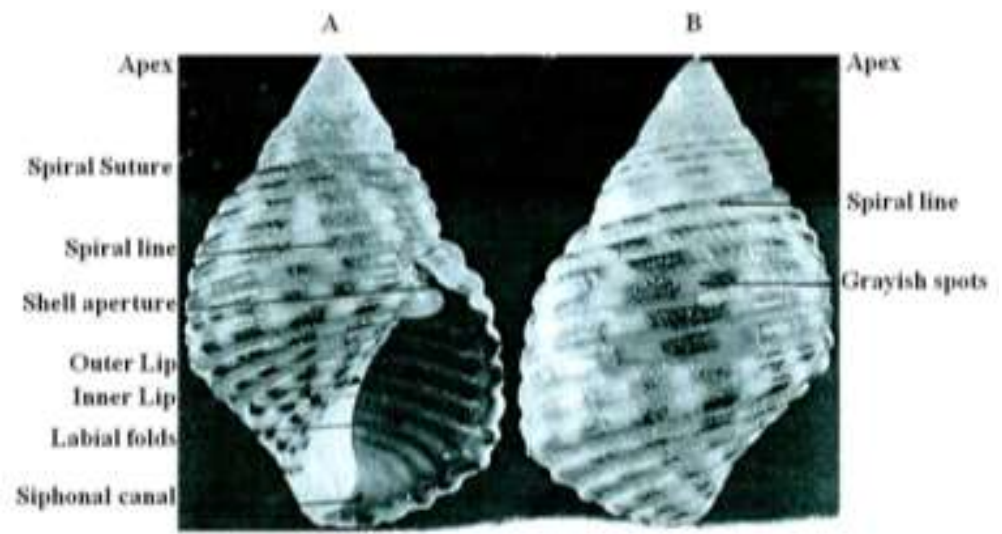

Fig. (6): Photomicrograph of shell of Planaxis sulcatus
(A) Ventral view
(B) Dorsal view)
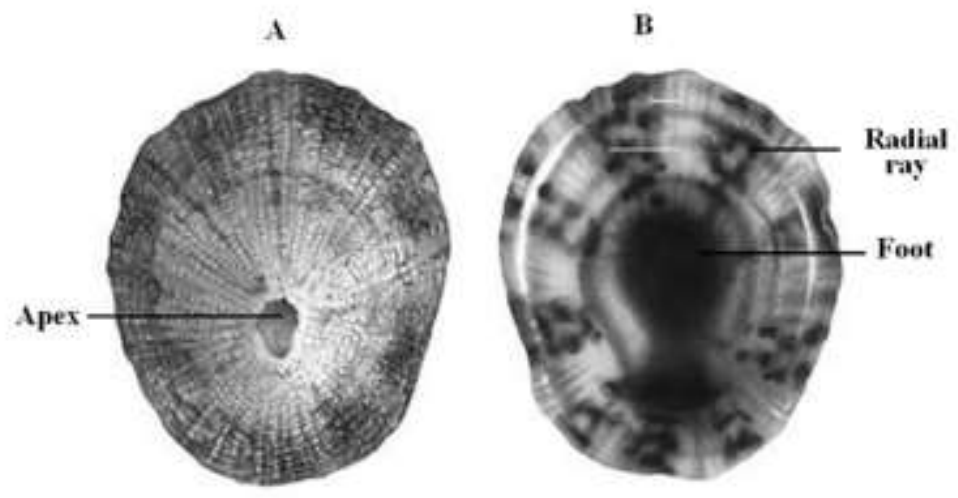

Fig. (7): Photomicrograph of shell of Cellana eucosmia
(B)
Dorsal view
(B) Ventral view 
Studies on some gastropods and echinoderms of the shallow water in the intertidal zone between Ras Mohamed and Dahab at the Red Sea, Egypt
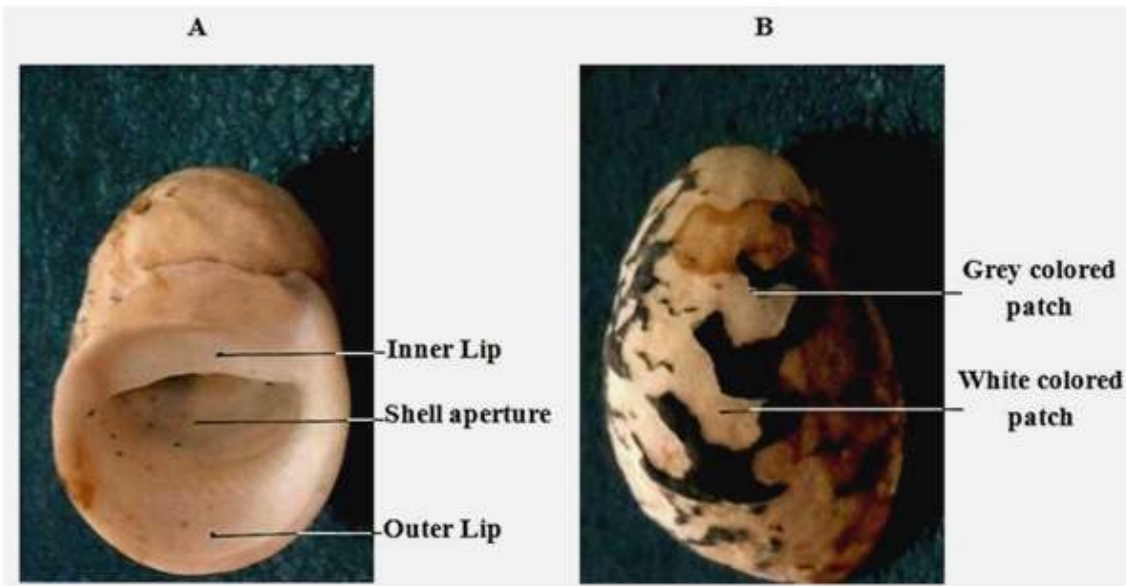

Fig. (8). Photomicrograph of shell of Nerita albicila

(A) Ventral view (B) Dorsal view

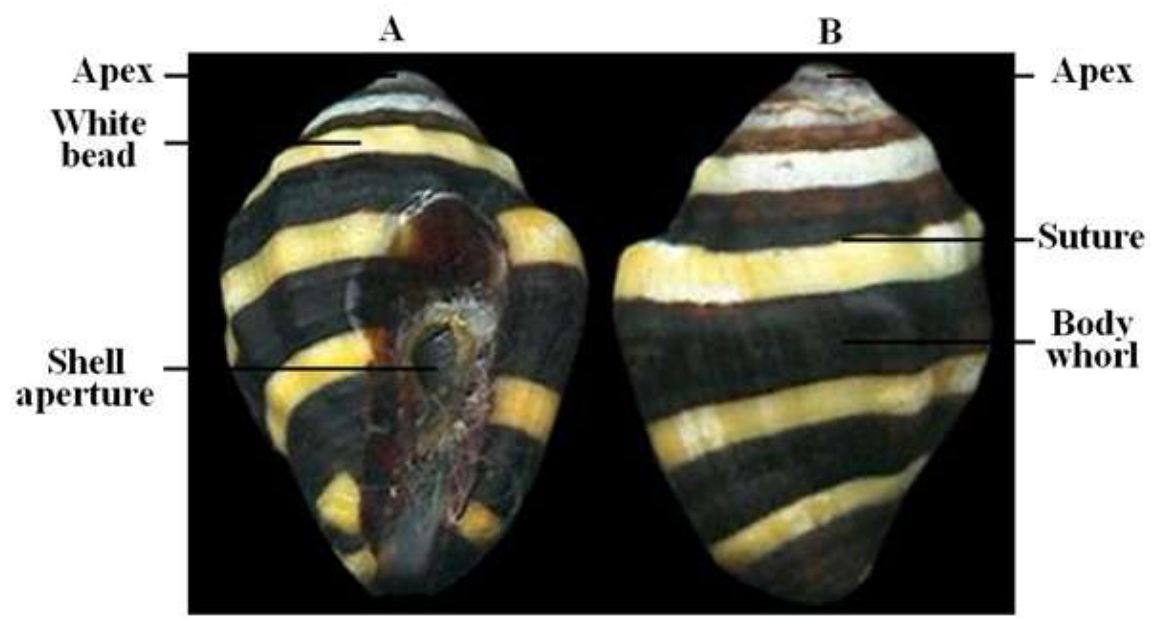

Fig. (9). Photomicrograph of shell of Engina mendicaria
(A) ventral view
(B) Dorsal view

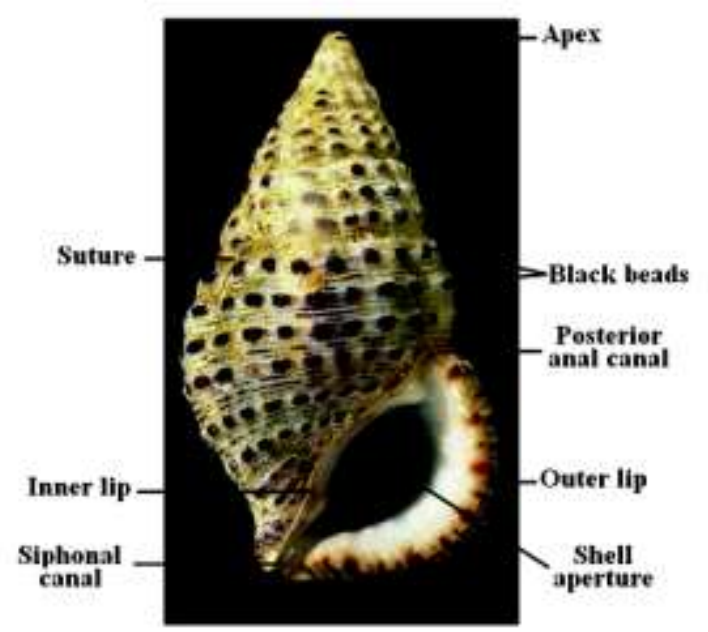

Fig. (10): Photomicrograph of ventral view of Clypeomorus bifasciata. 
Samir Beltagi

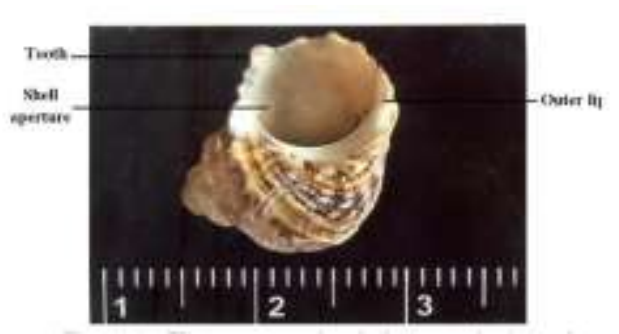

A

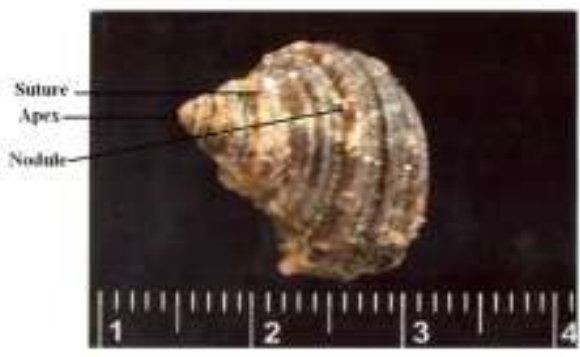

B

Fig. (11): Photomicrograph of shell of Nassarius coronatus.
(A) Ventral view
(B) Dorsal view

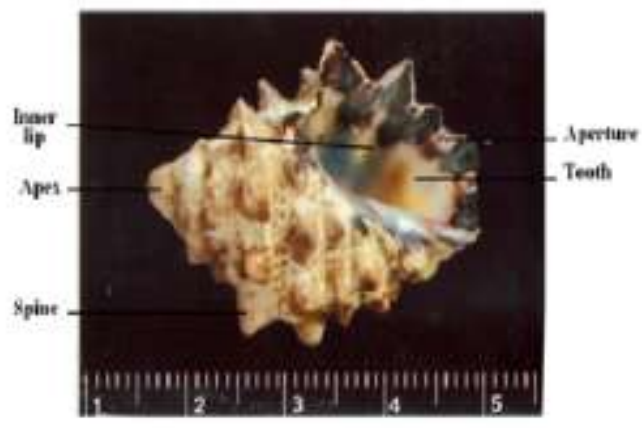

A

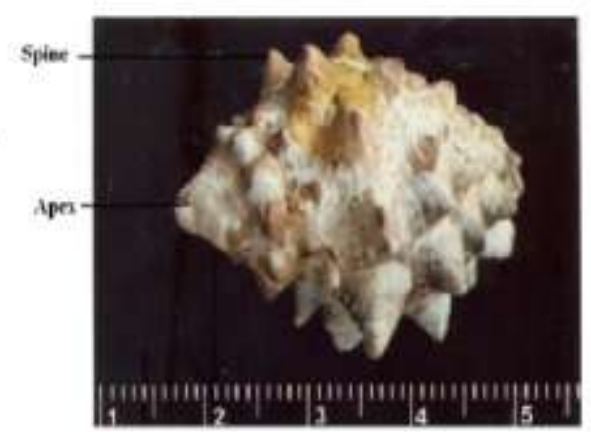

B

Fig. (12): Photomicrograph of shell of Drupella cornus.

(B) Ventral view

(B) Dorsal view

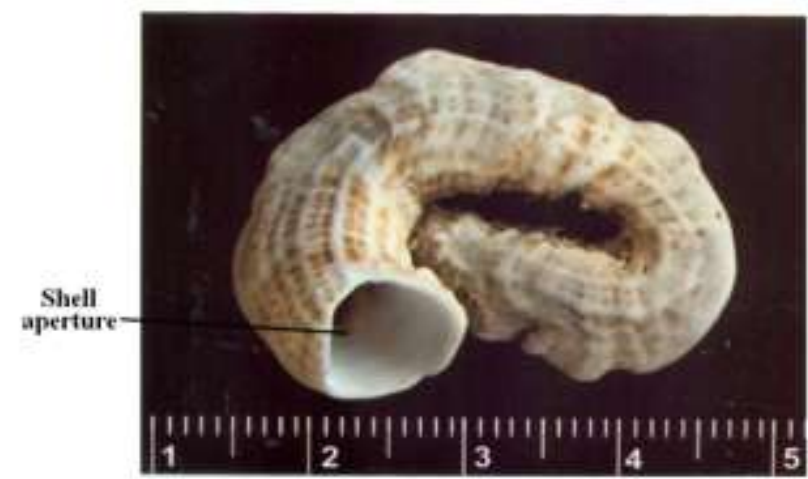

Fig. (13): Photomicrograph of shell of Dendropoma maximum

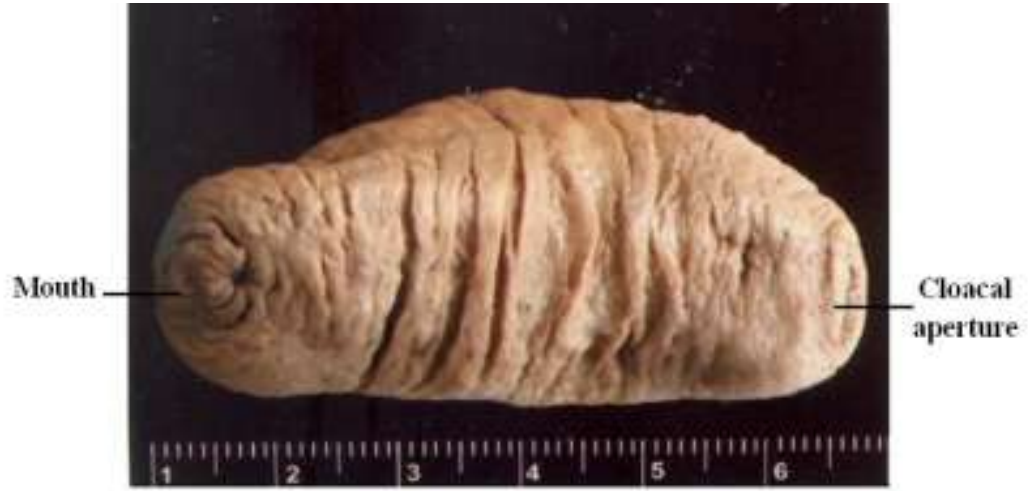

Fig. (14): Photomicrograph of Holothuria scabra. 
Studies on some gastropods and echinoderms of the shallow water in the intertidal zone between Ras Mohamed and Dahab at the Red Sea, Egypt

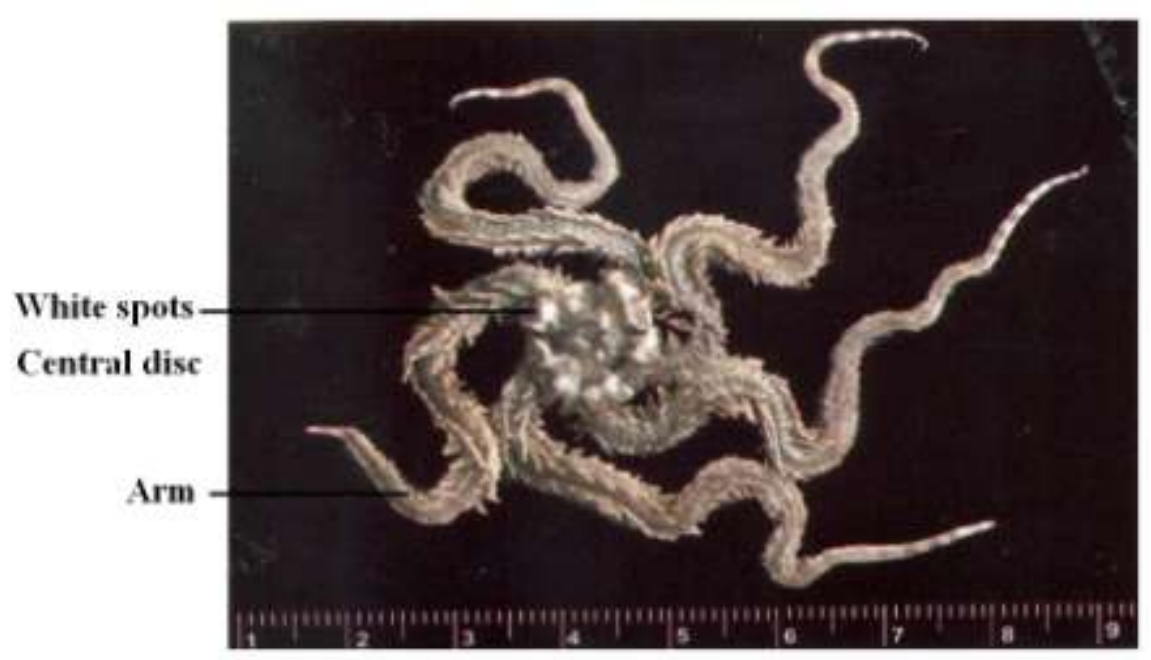

Fig. (15): Photomicrograph of the aboral surface of Ophiocomina nigra.

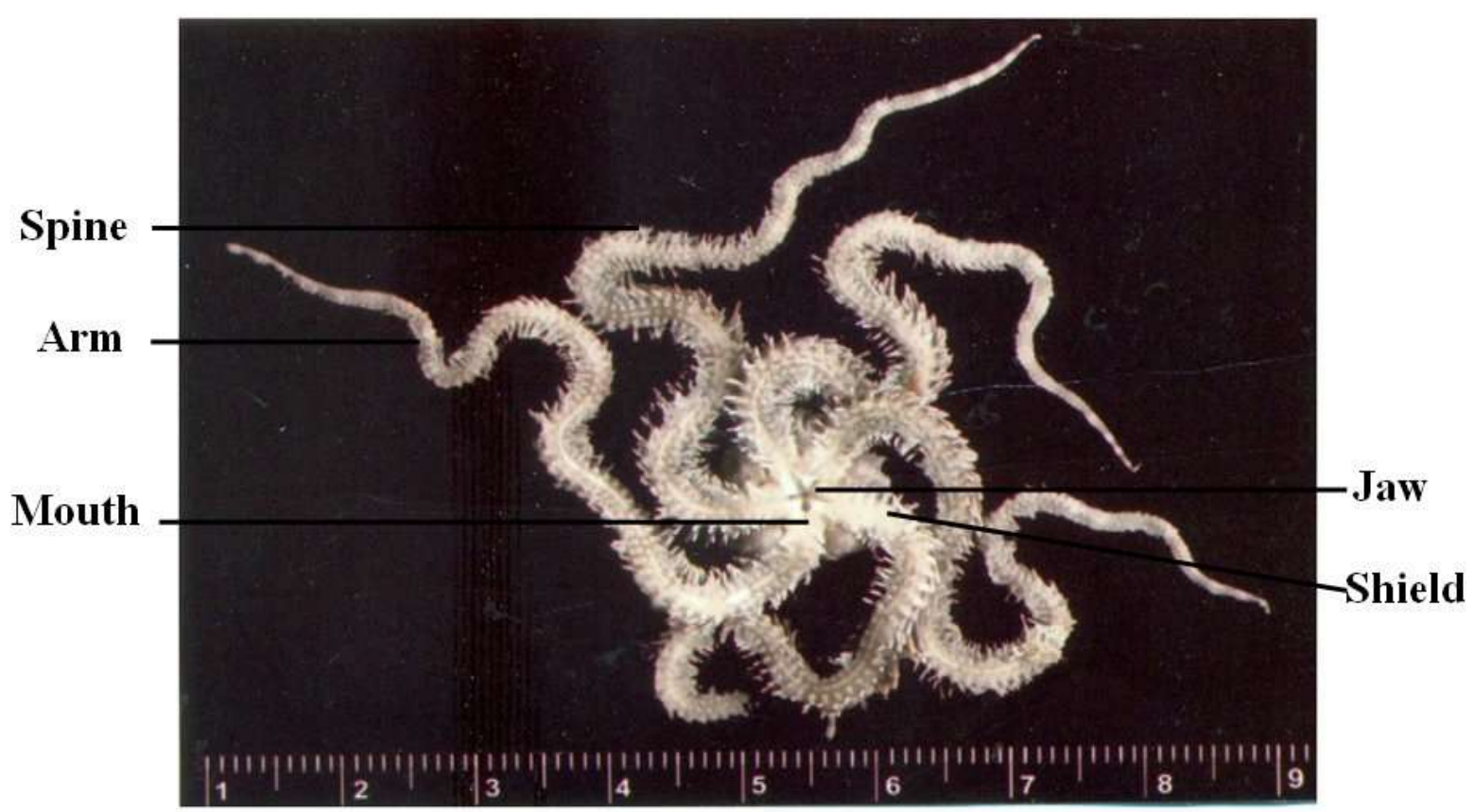

Fig. (16): Photomicrograph of the oral surface of Ophiocomina nigra. 


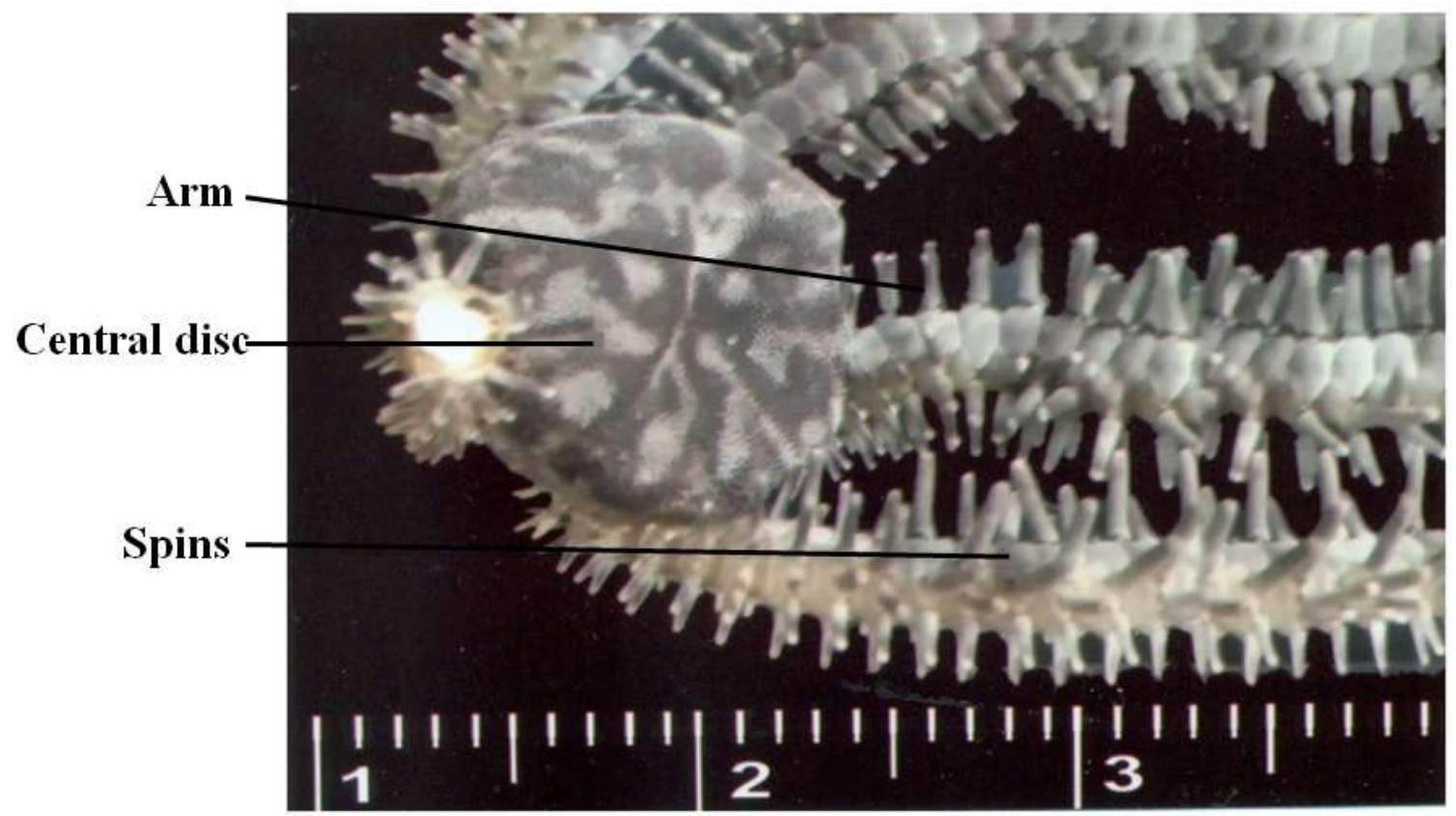

Fig. (17): Photomicrograph of the aboral surface of Ophiocomina nigra.

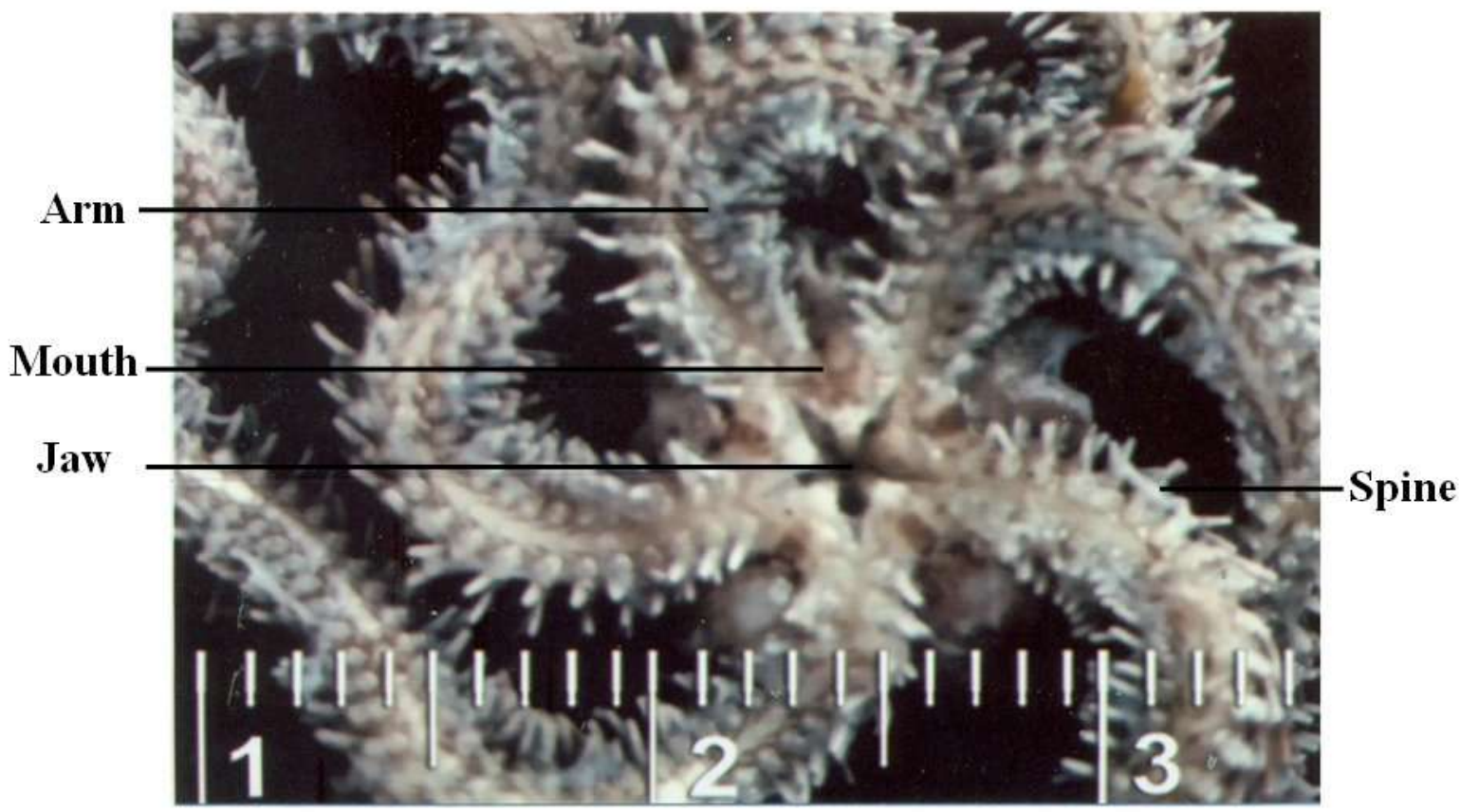

Fig. (18): Photomicrograph of the oral surface of Ophiocomina nigra. 
Studies on some gastropods and echinoderms of the shallow water in the intertidal zone between Ras Mohamed and Dahab at the Red Sea, Egypt

$$
\text { دراسات على بعض البطنقميات والجلاشوكيات فى المنطقة المد والجزر ما بين رأس محمد ودهب بالبحر الأحمر }
$$

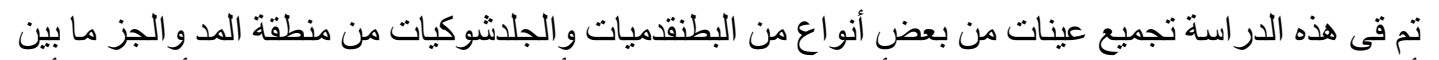

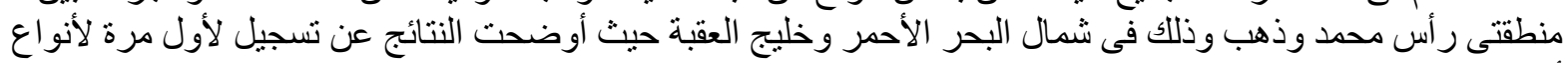

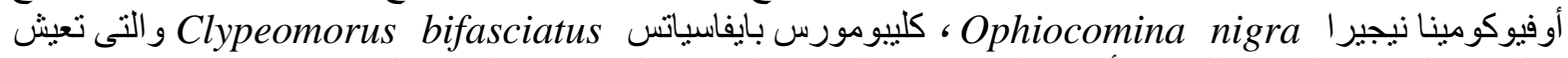

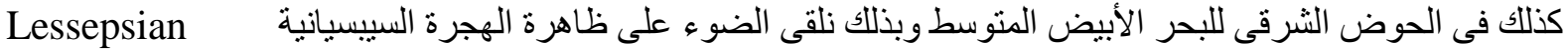
migration 